\title{
4
}

\section{Orientalism as Literary Criticism: The Reception of E. M. Forster's Passage to India}

\begin{abstract}
“A Mohammedan! How perfectly magnificent!" exclaimed Miss Quested. "Ronny, isn't that like your mother? While we talk about seeing the real India, she goes and sees it, and then forgets she's seen it."

E. M. Forster, A Passage to India (1924)

I don't myself like the phrase "the real India." I suspect it. It always makes me prick up my ears. But you can use it if you want to, either for the changes in her or for the unchanged. "Real" is at the service of all schools of thought.
\end{abstract}

E. M. Forster, “India Again” (1946)

In 1975 one of the more noted Indian literary critics of E. M. Forster, Vasant A. Shahane, edited a volume of essays by Indians on Forster's famous novel A Passage to India (1924). In the introduction to Focus on Forster's "A Passage to India" Shahane explains that the primary justification for the collection of essays was "to project an Indian critic's image of Forster's A Passage to India after about fifty years of its impact on this country and the English-speaking world. What is basically important in this approach is the Indianness of the native point of view, its process of evaluation and its validity." 1 The importance of Shahane's notion lies not so much in an emphasis on a unified Indian point of view, for in fact the collection can be interpreted as a heterogeneous emblem of diver-

1Vasant A. Shahane, ed., Focus on Forster's "A Passage to India": Indian Essays in Criticism (Bombay: Orient Longman, 1975), p. xiii; emphasis added. 
sity among Indian critics of this period, with essays ranging from a study of the symbolism of the cave, to a criticism of the novel's representation of race relations in India, to a stylistic analysis of the speech of the Indian characters in the novel. Rather, I believe that the significance of Shahane's articulation of "Indianness" inheres in its description of an opposition between the points of view of Indians and those of the Anglo-American intellectuals who had historically constituted the English literary tradition. It is a powerful opposition to the degree that it poses the notion of a native point of view over and against the ruling British perspective that traditionally considered India a colorful backdrop to the central British drama, and Indians as peripheral objects to be colonized and scrutinized rather than as possessing a point of view themselves. Indianness, in this sense, is proposed as an oppositional category, a means of articulating a position that is at once essential and eccentric to the English literary tradition. As Gauri Viswanathan argues, in Masks of Conquest: Literary Study and British Rule in India (1989), the institutionalization of English literature in India was a vehicle of British rule, and part of the imperial mission of educating colonial subjects in the literature and thought of England. The teaching of an English literary canon to Indian subjects had the unique role of justifying imperial rule to its subjects by inculcating assumptions of the superiority of western aesthetic principles and the complementary inferiority of the "impure" traditional literatures of the East. This ideological construction was supported, in concrete practical terms, by the distinctly separate formations of English literature in England and in India, by the exclusivity of the former institution and the subordination of the latter. Viswanathan points out that a gap existed between the functions and uses of literary education in its English and Indian contexts, manifested in different uses of the same curricula and the different values accorded to the various literary genres, as well as in the marginalization of the work of certain orientalist scholars such as William Jones in the context of Indian educational policy and the simultaneous elevation of these same scholars in British educational culture. ${ }^{2}$ It is as a critical counterpoint both to the function of English

\footnotetext{
${ }^{2}$ Gauri Viswanathan, Masks of Conquest: Literary Study and British Rule in India (New York: Columbia University Press, 1989). Viswanathan discusses the relationship between the institutionalization of English in India and the exercise of colonial power, as well as between the processes of curricular selection and the impulse to dominate and control.
} 
literature as an instrumental part of the British imperializing mission and to the closed elite superiority of the institution of English literary studies in England that Shahane's notion of the Indian point of view must be read and understood.

Shahane's comment is at once both obvious and subtle. On the face of things, it logically proposes that Indians ought to write about a novel that purports to be about India, and that what Indians can observe about $A$ Passage to India would necessarily be different from what other English speakers would find in it. As such, it calls attention to what postcolonial intellectuals such as Gayatri Spivak and Radha Radhakrishnan have distinguished as the difference between "representation" as "speaking for" a cultural and political locality and the "re-presentation" of an object, as in literary, artistic, or philosophical discourses. ${ }^{3}$ In other words, Shahane's comment points out that who is speaking may deserve as much attention as what is being said. At the same time, by foregrounding the history of an exclusion of Indian contributions as Indian, Shahane's volume both disrupts and alters the exclusivity of the English literary tradition itself. The Indian intervention into a tradition that subordinates and objectifies Indians transforms the set of conditions that regulates the range of possible articulations in that tradition: the criteria for inclusion and exclusion, the relationship of British scholar and Indian object of study, the question of what constitutes scholarly topics and scholarly inquiry. With these transformations, the discursive terrain on which English literature is constructed shifts; the fixed exclusivity of its structures is interrupted and displaced.

I begin this chapter with Shahane's articulation of "the Indianness of the native point of view" to stress that although the tradition of British orientalism includes many texts that establish the centrality of British power and identity through the literary construction of India and Indians as Other, the discourse of orientalism does not consist solely of univocal British-generated narratives. As we have seen in the previous chapters, discursive inscription and domination are hardly uni-

\footnotetext{
3See, for example, Gayatri Spivak's "Can the Subaltern Speak?" in Marxism and the Interpretation of Culture, ed. Cary Nelson and Lawrence Grossberg (Urbana: University of Illinois Press, 1988); and Radha Radhakrishnan, "Toward an Effective Intellectual: Foucault or Gramsci," in Intellectuals: Academics/Politics/Aesthetics, ed. Bruce Robbins (Minneapolis: University of Minnesota Press, 1990).
} 
form, but operate through a variety of unequal apparatuses at different moments. Heterogeneous, rather than homogeneous, orientalism includes a variety of positions, not only articulations of orientalist formations, but critiques of these formations as well. If the field includes that set of British texts in which the Indian is constituted as the ruled Other of the British ruler, it also includes the Indian textual responses provoked by and implicated in these texts. The discussion by Indian critics of Forster's controversial novel, and indeed all Indian criticism in English, must be considered as bearing a significant, if not paradoxical, relationship to the British-dominated institution of English literary study. Although some of the Indian work may be interpreted as reproducing traditional English ideas about literary aesthetics and genre, a significant portion of this scholarship cannot be dismissed as merely a quiescent colonial counterpart to the British literary tradition; rather it is one of the possible locations of significant challenges to the colonial hegemony that characterizes that tradition. I am not suggesting, by restricting my focus to the Indian debates in English about English literature, that it is the Indian relationship to the dominant formations of British institutions that legitimizes these articulations, nor that all contestations of these formations must be made within spaces recognized by the official discourse, for we can certainly locate equally, if not more important, insurrectionary and "subaltern" activities that occurred in spaces "outside" the British gaze. ${ }^{4}$ My point is rather that the debates between the Indian and Anglo-American literary critics about $A$ Passage to India provide a particularly illustrative example not only of the heterogeneity characteristic of discursive fields but, more particularly, of the dynamic process of intervention, dissent, and accommodation between emergent and dominant positions through which discursive formations are transformed. These debates ultimately illustrate that discursive hegemony is neither fixed nor monolithic, but that any existing hegemonic relationship exists in the context of ongoing conflicts and pressures from a variety of locations.

I begin with Shahane to signal, too, that this chapter is not primarily

4I am thinking here of the work of the historians of the Subaltern Studies Group, whose project is discussed further in the conclusion to the book, and the activities of worker and peasant rebellions to which these historians give their attention. See Guha and Spivak, Selected Subaltern Studies. 
about the novel $A$ Passage to India but about the intervention of Indian criticism on that novel, and the role that the Indian critics had in shifting the tradition of British orientalism. If I offer a brief discussion of the narrative of the novel, it is only to suggest some of the reasons why $A$ Passage to India became a social link and literary nexus of British and Indian concerns, and how it both contributed to and broke with orientalism. In previous chapters I have considered a variety of textsletters, travel narratives, and journals as well as novels-to propose heterogeneity as a method, to suggest that an accentuation of the heterogeneity that pervades the discourse of orientalism is one means of resisting its domination, its managing tropes. In this chapter I discuss another heterogeneous object-literary criticism-rather than reiterate the singularity of the novel-centered or author-centered study so characteristic of much literary criticism.

\section{British Orientalism and A Passage to India}

India lay at the core of the British imperial strategy in the late nineteenth and early twentieth centuries, "the brightest jewel in the imperial crown." 5 The British presence in India produced over a century and a half of orientalist literature-including journals, letters, novels, and stories-explicitly recording the British experience there. This literature arose from the circumstances of British rule and administration, which, since the eighteenth century, had placed British soldiers, missionaries, and civil service officers in India; at the same time, these writings contributed to and determined possible models for representing and developing British-Indian relations.

Like the French examples considered in the previous chapters, Lady Mary Wortley Montagu's Turkish Embassy Letters and Forster's Passage to India are also expressions of a complex plurality of concerns raised

5See Eric Hobsbawm, The Age of Empire, 1875-1914 (New York: Random House, 1987), chap. 3. Hobsbawm gives credence to the explanation that British expansion can be accounted for in part in terms of the British need to defend the land and maritime routes to India; as India was the core of British strategy, this required control of the short sea routes to the subcontinent (Egypt, the Middle East, the Red Sea, the Persian Gulf, and south Arabia) and the long sea routes (Cape of Good Hope, Singapore). India was essential to the British economy; 6o percent of British cotton exports went to India and the Far East, between 40 and 45 percent to India alone (pp. 68-69). 
by the histories of British encounters with the non-European world. Having been produced, however, by independent and unequal sets of social and historical pressures and circumstances, French and British orientalisms are clearly characterized by different literatures, and by distinct relationships between literary representations and the social situations that produce those representations. Even though both French and British orientalisms are products of European colonial encounters with non-Europeans, the French tradition does not often directly represent French colonial situations. Rather, the allegories about otherness in French orientalism tend to be literary figurations that detour or displace the problems of colonial encounter; in effect, colonialism is often not named or addressed. Furthermore, the French tradition frequently alludes to the literary figures and iconography of an Orient drawn from the previous literary tradition of orientalism, even if the narratives are associated with actual travels to the Middle East or Asia. For example, even though Flaubert's orientalist novel Salammbô emerges at a specific moment of French colonial expansion and war, and makes oblique, defamiliarized references to these circumstances, the novel does not explicitly record the history of the French presence in Egypt or Algeria; contemporary violence is displaced and rendered historically Other in the dramatization of the Punic Wars. In this sense, French colonialism is often buried beneath literary representations of the Orient as temporally remote, or fictions of a distanced and imaginary oriental world. The British literature, by contrast, while including its own poetic images of the Orient as an exotic past, also contains an important body of writing that explicitly records the contemporary British experience in the colonies; this is particularly true in the case of British narratives about the rule and administration of India. Furthermore, we might observe that the French and British orientalist traditions differ with regard to the narrative representations of the gendered relationship between the subject and object of orientalism. Whereas Flaubert's figuration of the Orient as an eroticized woman makes use of the rhetoric and narrative structure of masculine romantic desire, the British stance toward India may be generalized as being narrated, in contrast, in terms of a paternalistic metaphor that figures the colonial power as the father and the oriental object as his child, underdeveloped and in need of British protection. Much of the British literature about India documents the experi- 
ences of authors who lived as Anglo-Indians themselves, and portrays situations contemporaneous with the authors' lifetime. 6 Missionaries, colonial administrators, members and officials of the Indian Civil Service, and their wives, wrote about India as if its people were caught in a primordial past imagined as anterior to their own society before its evolution to civilization; they represent the British presence there as a high and holy mission to save souls and to deliver the Indians from pagan sexuality. Often the poetic melancholy of the exile and misfit dominates these works, contributing to the romantic self-characterizations of the Anglo-Indians as an aristocratic culture displaced among a savage, confusing, encroaching people. In "A Real Life City" (1888) Rudyard Kipling, who may represent the foremost exemplar of the British imperial position with regard to India, writes of the Bengalis' inability to manage their own city:

The damp, drainage-soaked soil is sick with the teeming life of a hundred years, and the Municipal Board list is choked with the names of natives-men of the breed born in and raised off this surfeited muckheap! . . They can put up with this filthiness. They cannot have feelings worth caring a rush for. Let them live quietly and hide away their money under our protection, while we tax them till they know through their purses the measure of their neglect in the past. ... Surely they might be content with all those things without entering into matters which they cannot, by the nature of their birth, understand.?

Kipling's invective carries out several characteristic rhetorical strategies. The language used to describe the Bengalis condemns them by attributing to them qualities of the nonhuman (for example, "breed"), while also, more significantly, physically and linguistically distancing them from the narrator's position, which is contemporary whereas they are mired in the past, healthy whereas they are sick, and singular

6See Benita Parry, Delusions and Discoveries: Studies on India in the British Imagination, 1880-1930 (Berkeley: University of California Press, 1972); Allen Greenberger, The British Image of India: A Study in the Literature of Imperialism, 1880-1960 (New York: Oxford University Press, 1969); Philip Mason, The Men Who Ruled India (London: Jonathan Cape, 1985); Michael Edwardes, Bound to Exile: The Victorians in India (London: Sidgwick and Jackson, 1969).

7Rudyard Kipling, "A Real Life City," first published in Pioneer, March 2, 1888; quoted in Parry, Delusions and Discourses, p. 212. For a discussion of twentieth-century assessments of Kipling as a spokesman for British imperialism, see Benita Parry, "The Contents and Discontents of Kipling's Imperialism," New Formations, no. 6 (Winter 1988): 49-63. 
whereas they are the multitude. Thus, not only is the narrating subject of the passage constituted as untouched and removed from the land, which is "damp," "drainage-soaked," and "sick," but also the independence and singularity of the narrative viewpoint is distinguished from the condition of the Bengali multitude, which is "teeming," and who are so numerous that the list is "choked with the names of natives."

The British narratives feature several persistent tropes through which Indians are figured: at times the Indians are represented as incomprehensible, erotic, and lawless; at others they are portrayed as unsophisticated and childlike. Two examples from an early-twentiethcentury moment of the tradition illustrate how both figurations serve a similar orientalist function of constructing the culturally different as Other in order to signify British culture as central, stable, and coherent. On the one hand, a district officer of the Indian Civil Service (I. C. S.) writes in 1924: “We are here to govern India as delegates of Christian and civilized power. We are here as representatives of Christ and Caesar to maintain this land against Shiva and Khalifa." 8 On the other hand, Sir Andrew H. L. Fraser, a former lieutenant governor of Bengal, writes in Among Rajahs and Ryots (1911) of his fond acquaintance with Indian country people, as opposed to educated urban Indians:

Often in the evening they would come round . . . telling me stories of their daily life or old legends connected with the country, and acquiring that kindly familiarity with a British officer which camp life induces, and which is so valuable in the administration of India. ... The simplicity of the country people, their confidence in the officers whom they learned to trust, their patient endurance of the severest trials, and their deep gratitude for all that was done for them, made an impression on our minds which will never be effaced. ${ }^{9}$

Fraser's description stresses the intimacy and familiarity between the British officers and the country people and praises the Indians for their simple, trusting behavior. For him, Indians are not wild and uncontrollable but rather agreeably comprehensible and in need of British

\footnotetext{
${ }^{8}$ Al. Carthill [Calcraft-Huntingdon], The Lost Dominion (London: Blackwood, 1924), p.

${ }^{9}$ Andrew H. L. Fraser, Among Rajahs and Ryots (London: Seeley, 1911), pp. 89-91.
} 236. 
compassion and protection. These narrative voices of the missionary, the protector of British dominion, and the sympathetic I.C.S. officer all form parts of a discourse that figures Indian otherness to construct British subjectivity, elaborating a logic of binary complementarity in which Indian subservience becomes a signifier for British superiority. Whether India is figured as a primitive culture to be civilized or as an inferior culture to be protected, both representations of India refer to, and signify, the necessary roles of British savior and guardian. Above all, the British representations of India and Indians establish as British the position of narrative agency or subjectivity; the Indian people, landscapes, and images occupy the position of objects brought into focus by the British subject's point of view. What becomes accepted as Indian life is the textual product of British viewing and scrutiny.

Although the binary relationship of British narrating subject and Indian object of description is the rule, occasionally a mutual regard between Briton and Indian is implied. Some of the British accounts are punctuated by passages that, in acknowledging the Indian scrutiny of the British, constitute British subjectivity in relation to an anxiety about, or a consciousness of, the Indian gaze. Inasmuch as Indian objectivity is rendered by the British subject's gaze, British subjectivity is constructed as being dependent on recognition by the Indian. For example, the narrator of Y. Endrikar's Gamblers in Happiness (1930) represents an awareness that he may be the object gazed upon when he writes of attending church for the express purpose of being seen by Indians: "I go on principle in India to show that I am not ashamed of my religion. . . . In England I confess I take a holiday." 10 Endrikar finds it necessary to represent the ruling race in relation to what he projects the expectations of the Indians to be. Because he understands the Indians to be deeply religious, he thus imagines that Indians may be apt to judge the British as much less spiritual than themselves in spite of their regular church attendance. In other words, the Englishman comprehends himself and his own subjectivity through seeing himself as existing for the Other, understanding himself as being seen by the Other. This formation is echoed in Sir Evan Maconochie's Life in the Indian Civil Service (1926):

10Y. Endrikar, Gamblers in Happiness (London: Heath Cranton, 1930), p. 155. 
To the raiyat the visit of a "saheb" or a casual meeting with one has some of the qualities of excitement, which a great statesman once attributed to a circus, in the case of his English counterpart. It will be talked of for days over the village fire and remembered for years. The white man will be sized up shrewdly and frankly. So take heed unto your manners and your habits! The day is fast approaching when many villages will have their wireless set, and the Patel and his family will drive off in their bulging Ford to the nearest cinema, and then the villager will have more to think about and be far less attractive to meet. ${ }^{11}$

Like Endrikar, Maconochie also reveals an anxious consciousness of the Indian gaze in his description of how the entire village will "size up" the British visitor "shrewdly and frankly." Maconochie further associates this ability to view the British discriminately with the development of modernization and the introduction of products of industry into the Indian village. His association of Indian subjectivity with industrialization and westernization articulates the colonialist ideology which proposes that western imperial policy is responsible for "educating" India, that modernization is the eventual by-product of the British occupation of India, and that this modernization is made possible through contact with the West. Another version of this ideology is the notion that it is western liberal humanism that engenders an independent Indian gaze and subjectivity, indeed that English education permitted the growth of Indian nationalism by providing Indians with the tools to question colonial authority. ${ }^{12}$ This progressive structure of development is itself an ideological narrative that continues today to subordinate countries and communities of the Third World to the modernizing West. ${ }^{13}$ Beneath the colonialist ideology of Maco-

11Even Maconochie, Life in the Indian Civil Service (London: Chapman and Hall, 1926), pp. 48-49.

${ }^{12}$ For a most persuasive critique of this colonialist discourse about Indian development, see Gauri Viswanathan's analyses of Bruce McCully's English Education and the Origins of Indian Nationalism (1942) and David Kopf's British Orientalism and the Bengal Renaissance (1969), in Masks of Conquests.

${ }^{13}$ Interesting work has been done in anthropology to examine the ideological content and agenda of the "discourse of development." See, for example, Arturo Escobar, "Discourse and Power in Development: Michel Foucault and the Relevance of His Work to the Third World," Alternatives 10 (Winter 1984-85): 377-400. On the narrative of development, and its function in aesthetic and political discourses of representation that subordinate localities, as well as ethnic and class minorities, see David Lloyd, "Genet's Genealogy: European Minorities and the Ends of Canon," in The Nature and Context of 
nochie's statements, however, is a more interesting rhetorical fluctuation, a linguistic tremor that registers the shift from an earlier formation-of knowing British subject and known Indian object-to another formation in which British omnipotence gives way to anxiety and Indian impotence is refigured as a powerful and constitutive authority. Whereas India previously served as spectacle for the colonizing viewer, in Maconochie's description it is the British "saheb" who is rendered as "circus," as the viewed object of study.

As we have seen, then, although British orientalist discourse about India begins with the British construction of the Indian as silent, nonEnglish-speaking Other, ultimately, by the twentieth century, this discourse posits Indo-British relations as an exchange in which British and Indians reciprocally construct one another, each subject position existing within the context of the other, dependent on the recognition of the other. These later British articulations of Indian scrutiny and judgment express a British consciousness of the Indian as subject, and express in the discourse the vulnerability of British rule in the hegemonic relationship between colonizer and colonized. British anxiety about the Indian as subject reveals an implicit acknowledgment of Indian subjectivity, despite the discourse's overt exclusion of Indians from subject positions. The pressure built up by Indians on the structures of exclusion-not simply at this small space opened up in the literary discourse, but at all levels of the social text where Indians were subordinated or ignored-is registered by this anxious notion of Indian subjectivity embedded within the British writings about Indians. Ironically, the English-language representation of Indians as subjects under colonial rule constitutes one of the occasions through which Indian writing subjectivity in English is admitted; it is with an analogous irony that I consider the Indian Forster criticism as one example of the emergent Indian position embedded within the British-dominated discourse of English literature itself.

In the tradition of British orientalism, E. M. Forster's Passage to India figures prominently as both a turning point in the tradition itself and a nexus of critical attention. Although the centrality of Forster's novel to the literature of British imperialism is indubitable, the purpose of my

Minority Discourse, ed. Abdul JanMohamed and David Lloyd (Oxford: Oxford University Press, 1990). 
discussion is not to render Forster's novel as an exemplary representation of the tradition. Rather, what makes $A$ Passage to India interesting, indeed atypical of the tradition, is the vigor and heterogeneity of the literary debates the novel aroused, and the fact that it continued to be the focus of both English and Indian criticism throughout the 1950s, 1960s, and 1970s. There were other novels, such as the journalist Edmund Candler's Abdication (1922) and the I.C.S. missionary Edward Thompson's Indian Day (1927), which portrayed the Indian predicament sympathetically and even went so far as to be critical of British imperialism and the attitudes of the Anglo-Indians; these novels, however, cannot be said to have had an equal impact on AngloAmerican and Indian literary audiences. Although some of this attention by both Anglo-American and Indian critics to $A$ Passage to India may have been due to Forster's status as a successful novelist and member of the Bloomsbury group, the timely and unique qualities of the novel's drama also played a role. The Indian protagonist, Dr. Aziz, falsely accused of raping a visiting Englishwoman, Adela Quested; the evocative and poetic descriptions of the Indian landscape and climate; and the tripartite novel's controversial ending section, "Temple," in which the Hindu ceremony of Gokul Ashtami is described in detail: all these elements mark A Passage to India as different from other novels about India. Cultural misapprehensions, dramatized through the cross-cultural friendships between the Indian Aziz and the Englishman Cyril Fielding, and between the Muslim Aziz and the Christian Mrs. Moore, further distinguish the novel. In short, the central drama of Adela's false accusation of Aziz thematizes the misapprehension of India and Indians by the British, and the Indians' continual misreading of the intentions of the British and the portrait of the ensuing hysteria among the Anglo-Indians may be interpreted as constituting a strong indictment of the British imperial posture. Furthermore, the novel departs from traditional characterizations of Indo-British relations in the emphases it places on Indian characters, culture, and religion, as well as on friendships between Britons and Indians.

Yet, although the novel differs from the traditional British literary attitude toward India, it also responds to, and is situated within, this very tradition, and thus retains particular residues of the British narrative tradition about India. The fluctuations in narrative perspective provide some illustrations of the novel's ambivalent relation to the 
earlier stances of British orientalism. Throughout the novel, there are many moments when the narrative perspective shifts to include the points of view of both the English and the Indian characters, accomplishing, on the level of narration, a dissolution of the oppositional relationship between British and Indian elements. Although this narrative technique challenges the customary relation of British narrator and Indian object of description, the narrative perspective at times returns to a position outside the drama, a position culturally coded as British and distinctly non-Indian. For example, in these descriptions of Aziz the narrative perspective is similar to one inherited from earlier British orientalism:

Like most Orientals, Aziz overrated hospitality, mistaking it for intimacy, and not seeing that it is tainted with the sense of possession. It was only when Mrs. Moore or Fielding was near him that he saw further, and knew that it is more blessed to receive than to give.

Suspicion in the Oriental is a sort of malignant tumor, a mental malady, that makes him self-conscious and unfriendly suddenly; he trusts and mistrusts at the same time in a way the Westerner cannot comprehend. It is his demon, as the Westerner's is hypocrisy. ${ }^{14}$

In both passages the narrator generalizes Aziz's emotionality as a racial and ethnic trait. In these cases the narrator assumes the British orientalist posture inherited from the previous tradition, while at other times the narrative calls attention to the paradoxical status and location of the narrator.

An example of the paradoxical situation of the British narrator of Indian scenes occurs during the description of the Hindu ceremony in the last section of the novel:

Hindus sat on either side of the carpet where they could find room, or overflowed into the adjoining corridors and the courtyard-Hindus, Hindus only, mild-featured men, mostly villagers, for whom anything outside their villages passed in a dream. They were the toiling ryot, whom some call the real India. Mixed with them sat a few tradesmen out of the little town, officials, courtiers, scions of the ruling house. Schoolboys kept inefficient order. The assembly was in a tender, happy state unknown to an English crowd. (pp. 283-84)

${ }^{14}$ E. M. Forster, A Passage to India (New York: Harcourt, Brace and World, 1924), pp. 142-43, 279-80. 
The narrative describes a Hindu ceremony from which all but Hindus are excluded, and underscores this exclusivity with several deictic markers: "Hindus, Hindus only" and "a tender, happy state unknown to an English crowd." The situation of description foregrounds the paradox that the narrator must be at once absent as excluded nonHindu, yet present as narrative witness of the ceremony. The very marking of this paradox foregrounds and thematizes the narrative problems of a British novel about India and Indians, and confesses the structural limitations of the British subject's ability to render Indians as other than objects of description. The Indian in a British novel is always marked by British presence, and rendered by means of British observations. This is expressed later in the same scene when an inscription to honor a Hindu supreme being is "composed in English to indicate His universality," and "consisted, by an unfortunate slip of the draughtsman, of the words, 'God si love'" (p. 285). Not only does this presence of English in a gathering of "Hindus, Hindus only" draw attention to the pervasive extent of British rule, but also the miscomposition "God si love" is a comic emblem of two cultural misunderstandings, the rendering of the Hindu concept into English and the Indian appropriation of this Anglicized rendition. The predicament of ambivalence described in this scene is echoed in the many instances of cultural misinterpretation that fill the novel: the Englishwomen cannot understand Mrs. Bhattacharya's inviting them to her home at a time when she will not be there; Aziz mistakes Fielding's remark about "post-impressionism" as a condescension; Adela misunderstands Muslims when she asks Aziz if he has more than one wife, and then tragically misconceives Indians when she hallucinates the attack in the cave; Aziz mistakes the facts of Fielding's marriage; and so on. The novel contains an assortment of anecdotes that record the misinterpretation of the one culture by the other, and in this portrait of IndoBritish misreadings, the problematic western representation of the Orient is pointedly thematized.

But the text of the novel alone does not explain the status of $A$ Passage to India as a turning point in British orientalism. Its importance is rather to a great extent the result of the way the novel has been constituted and appropriated by a variety of schools of criticism. Since A Passage to India has attracted criticism from British, North American, and particularly Indian commentators, the reception of the novel has 
been marked by a relationship in which the Anglo-American and the Indian literary traditions mutually construct each other by commenting on this text that links and emblematizes a variety of both groups' national concerns. The attention of the Indian scholars has contributed to the novel's singular prominence in the field of English literature; at the same time Forster's novel has offered an occasion for Indians to enter the discourse and has been an important vehicle for certain kinds of Indian critical visibility.

\section{Orientalism and Anglo-American Forster Criticism}

It is noteworthy that one of the first significant dialogues between Indian and British intellectuals should occur in the discussion of a British novel, which in itself represents one of the patterns of British rule and Indian accommodation: the Indian acceptance of the condition that this dialogue take place in the English language and deal with English texts. Forster's enigmatic novel about Indo-British misunderstanding became a locus of these dialogues not only because it was a British novel that represented with sympathy the Indian position in Indo-British relations, and one of the first to feature an Indian protagonist, but more practically because its publication coincided with an increase in the number of Indians entering the discipline of English literature. Functioning as a "rupture" in the British representations of Indians, A Passage to India provided an occasion for Indian entry into what had previously been a British-dominated tradition. The Indian scholarship about the Forster novel is situated, and so marks itself, within the context of British and North American critical work; indeed, every Indian critic writing on A Passage to India writes in English and addresses or responds to previous work by British and American figures in Forster criticism (and, quite often, also by Forster himself). In this sense, the Indian commentary is always defined in relation to the presence of Anglo-American criticism; the dialogues of dissent and accommodation within the field of Forster criticism reproduce the larger "dialogues" of British power, occupation, and administration, and Indian subjugation, noncooperation, and independence.

At the risk of oversimplification, it may be useful to characterize 
some of the historical patterns particular to the execution of British rule and the development of Indian independence, and relevant to the tensions and dissensions present in the Indian debates about $A$ Passage to India. The British came to power in India in the eighteenth century by defeating the Mughal princes who had ruled since the sixteenth century, and through turning the instability of Mughal control to the British advantage. One of the primary means by which the British continued their economic control over ever larger portions of India while securing and expanding cultural control over the people was through a rigorous anglicization of the Indian landlord and merchantbanker classes; for the classes of Indians who eventually aided the British in establishing regional controls over India in the eighteenth and nineteenth century were schooled in the extensive legal, administrative, and educational system imposed by the British. After the Great Mutiny of 1857 , however, the British redirected these efforts to rule through anglicization of the Indians, and in order to maintain British rule paid more attention to what they understood to be the traditional Indian system of caste and privilege. Eric Wolf argues that although the Mutiny was defeated, the violent outbreaks of the $1850 \mathrm{~s}$ brought a sudden realization that the British control over India was tenuous, and the rulers "abandoned the idea of reforming India through the application of English liberal ideas, and strove instead to strengthen what they regarded as Indian traditions." 15 There arose what Francis Hutchins has called an "attempted orientalization of British rule." This orientalization presumed that "Indians could not be changed, and furthermore that the superiority of the British character presented no obstacles to a full understanding of Indians." This policy advocated separation and hierarchization of the British and Indians. As Englishmen constructed a myth of their own omniscience, there also evolved the myth of the "real India." This was conceived of as "the ancient India of the countryside; and of retainers and dependents of British power, of princes, peasants, and minority groups. Indians who lived in cities, engaged in business and the professions, who were not dependent on British favor, without an interest in preserving for themselves a privileged position guaranteed by British might, were desig-

\footnotetext{
${ }^{15}$ Eric Wolf, Europe and the People without History (Berkeley: University of California Press, 1982), pp. 251-52.
} 
nated as 'unrepresentative.'"16 Thus, it was through a British notion of Indianization that British hegemony was maintained during the latter portion of the century. In other words, the British administration of India was initially executed through the compliance of the Indian upper classes, and through an anglicization of the Indians, whereas in the post-Mutiny period, faced with the possibility of losing India as a dominion, the British attempted to reinforce traditional Indian hierarchies to quell dissent and maintain rule. In the early twentieth century it was India's identification of itself as "Indian," and the power of this notion to unify diverse Indians-Hindus, Muslims, Sikhs, Jains, "representative" or not-which enabled the Indians to demand independence as a nation. By the 1920 Indian-led nationalist and independence movements had grown, fueled by peasant and worker rebellions, as well as by many successful actions of noncooperation and civil disobedience practiced under the direction of Mahatma Gandhi. India achieved independence in 1947.

In the set of debates about $A$ Passage to India among the Indian critics, one can trace a similar controversy regarding the roles of anglicization and Indianization with regard to the Indian critical project. If it is fair to generalize and say that the very instruments and strategies of British rule (that is, the British project of Indianization following 1850) provided some of the foundational context for the emergence of the Indian independence movement, then one can see analogous tensions reflected in the Indian discussions of Forster's novel. In the debates about Hindu and Islamic influences on Forster's novel, about the novel's political or religious merits, and about the novel's representation of Indians, significant members of the group of Indian critics take positions that might lead to an argument for an Indianization of English literary criticism, and particularly of English literary criticism about Forster. The emergence of an Indian literary critical voice is focused in the discussion of Forster's novel, a novel whose very writing and circumstances of writing (the social and political policies that placed Forster in India at the time, for example) express the conditions of British imperial rule. In other words, without promoting the colonialist assumption that Indian development was set in motion by

\footnotetext{
16Francis Hutchins, The Illusion of Permanence: British Imperialism in India (Princeton: Princeton University Press, 1967), pp. 155, 156. See also Michael Edwardes, British India, 1772-1947: A Survey of the Nature and Effects of Alien Rule (New York: Taplinger, 1967).
} 
British imperialism, one can still remark that the very history of British rule-including not only the elaborate British educational and administrative occupation of India but also the imposition of the English language itself-contributed to the apparatuses, in paradoxically both a productive and a regulatory sense, through which these Indian intellectuals came to study and write about English literature. The irony remains that the dialogues between English, American, and Indian intellectuals, addressed, in English, the subject of an Englishman's novel; it was only in the 1980 s that dialogues between these communities began to take place around Indian literary works in English. ${ }^{17}$

In the discourse of British orientalism, the Anglo-American literary critical response to $A$ Passage to India functions in many ways as an analogue for the earlier British position toward Indians. Just as the British narrating subject in literary orientalism had access to language and to the representation of Indians, Anglo-American literary criticism, from the period beginning in the late 1920 s through the 1960s, reiterated this exclusion of Indians from the discourse. This exclusion was performed, on the one hand, by critics who either dismissed or studiously overlooked discussion of India or Indians as factors in the literary value of the novel and, on the other hand, by the structure of the literary institution itself, which reflected the scarcity of Indian critics writing about English literature. For although Bhupal Singh's landmark book of criticism, A Survey of Anglo-Indian Fiction, which includes a short chapter on A Passage to India, appeared in 1934, the greater part of Indian criticism of Forster emerged during the $1950 \mathrm{~s}$ and 1960s, after independence, and after it became acceptable for a certain number of Indians to enter the British-dominated field.

Curiously, until after Forster's death in 1970, the majority of AngloAmerican criticism on $A$ Passage to India was written by critics in the United States. ${ }^{18}$ Lionel Trilling explained the American attention as

\footnotetext{
${ }^{17} \mathrm{I}$ am referring here to the relatively recent Anglo-American critical attention given to Indian immigrant and diaspora novelists such as Bharati Mukherjee, Salman Rushdie, and Hanif Kureishi, and to the interpretation of Indian literature in the context of colonialism and postcolonialism. See, for example, Timothy Brennan, Salman Rushdie and the Third World (New York: St. Martin's, 1989), and South Atlantic Quarterly 87, no. 1 (Winter 1988), on Third World literatures.

${ }^{18}$ Other than Rose Macaulay's 1938 book-length study of Forster, the attention given to A Passage to India by British critics was primarily editorial (for example, Oliver
} 
being due to "the superiority Americans could feel at the English botch of India." 19 The appreciations of Forster's work in the United States might be characterized as thematic, archetypal, and formalist; they have viewed the novel in terms that strictly separate literary and philosophical criteria from issues such as the history of the British presence in India and its influence on the novel or, equally, the novel's representation of these social and historical circumstances. ${ }^{20}$ Most of the American criticism of the 1950 os was characterized by this distinct separation of "literary" from historical context: E. K. Brown's study of rhythm (1950), Reuben A. Brower's analysis of irony (1951), and Gertrude White's essay on the dialectical pattern of the novel (1953) exemplify this type of study. In the 1960s, critics such as Frederick Crews (1962), Wilfrid Stone (1966), and George Thomson (1967) continued to discuss the novel in terms of the limits of its humanism, its use of symbols and archetypes, the author's narrative voice, and the tripartite dramatic structure.

Within this formalist approach, the novel was most often accounted for by being seen as the culminating treatment of themes introduced in Forster's previous novels. In considering the novel within a chrono-

Stallybrass's Abinger editions of Forster's novels). Most criticism during Forster's lifetime focused on the earlier novels (which seem more easily characterized as Edwardian, as not modernist). After his death, when most of the material revealing Forster's homosexuality emerged and became accessible, a number of British biographies and works of criticism considered Forster in terms of his sexuality. See John Colmer, E. M. Forster: The Personal Voice (London: Routledge and Kegan Paul, 1975); Francis King, E. M. Forster and His World (London: Thames and Hudson, 1975); and especially P. N. Furbank's authorized biography E. M. Forster: A Life (New York: Harcourt Brace Jovanovich, 1977).

My discussion does not specifically concern itself with Forster's homosexuality. What is of interest to me is the role attributed to India and Forster's Indian friends by the post-1970 British biographies of Forster-that is, how the biographers form a narrative that reconciles Forster's two notable "deviant" fascinations, with India and with other men. King's biography, for example, which is very much concerned with Forster's "pederasty" and "onanism," associates Forster's first trip to India with his homosexual interest in Syed Ross Masood and represents Forster's interest in India as homoerotic; there is no mention of any cultural or political interest in India and the Indian people, a view that is, of course, in absolute contrast with the Indian discourse, which never mentions Forster's homosexuality and represents Forster's interest in India as purely cultural and politically sympathetic.

${ }^{19}$ Lionel Trilling, E. M. Forster (Norfolk: New Directions, 1943), p. 123.

${ }^{20}$ Greenberger, The British Image of India, and Parry, Delusions and Discoveries, as well as M. M. Mahood, The Colonial Encounter (Totowa, N.J.: Rowman and Littlefield, 1977), are some of the few British and American works for which the context of British colonial rule of India is crucial to the discussion of the novel. 
logical development of themes traced through The Longest Journey to $A$ Room With a View to Howards End, as did Peter Burra (1934), Crews, and Thomson, the criticism leveled the different social and political positions of Indians. India is considered a colorful backdrop, a literary device or leitmotif, a new setting in which to treat the same questions. Burra writes about the theme of "the clash of opposites": "The intrusion of the English at Mau is incidental and designed only to reintroduce what is the real theme of the book-the friendship of Fielding and Dr. Aziz. The rocks that rise between them on their last ride together, the horses that swerve apart-they symbolize Indian differences, it is true, but differences that are not more great, only more particular, than the differences that exist between any two men, between Philip and Gino, Ricky and Stephen, Schlegels and Wilcoxes."21 Later critics such as Barbara Rosecrance (1982) considered A Passage to India to be an eccentric break with the previous novels; yet this inverse interpretation serves an identical purpose-that is, avoiding an engagement with the novel's treatment of Indian difference through a logic that constructs it as anomalous, as too different. Rosecrance contrasts the early Forster with the late: "But $A$ Passage to India presents a new cosmos. Vanished are Italian landscapes and English countryside. Instead, Forster has given us India, monstrous, extraordinary, chaotic, a context in which humanity can never be easy, a symbol, rather of man's helplessness and alienation." 22 The interpretations that find continuity are not dissimilar to those that find discontinuity; both narratives construct relationships among Forster's novels rather than engaging with the historical circumstances of the British in India, of which the novel is a representation as well as a product.

The 1950 also produced a strain of "philosophical" commentaries on the novel among the American critics. Glen O. Allen (1955) and James McConkey (1957) considered the Indian influences on the novel's structure and symbology. These American interpretations of the novel represented the first attempts to take as a central problem of interpretation the forceful role of Indian culture and symbols. Allen's and McConkey's readings of the novel as a dramatization of Hindu concepts stimulated both interest and controversy among the Indian

\footnotetext{
21Peter Burra, The Novels of E. M. Forster (London: Whitefriars Press, 1934), p. 35.

22Barbara Rosecrance, Forster's Narrative Vision (Ithaca: Cornell University Press, 1982), p. 241.
} 
critics. Indeed, the Indian critics who examine Hindu symbology both address and specifically take issue with Allen and McConkey; M. Sivaramakrishna, among many others, declares that Allen's view of the margas is "confused" and "in error." 23 The particulars of this debate are discussed later in this chapter, but what is important to these remarks about the dialogic and mutually constitutive relationship between the Anglo-American and Indian criticisms is that the Indian entrance into the discourse of orientalism is made possible by the address of, and in this case the refutation of, Anglo-American representations of Indians; the representation and appropriation of India as Other offers the opening for the Indian response that follows.

\section{The Indian Debates}

When Indian criticism on Forster generally began to emerge during the 1950 and 1960s, Forster, at that time in his mature seventies and eighties, was offering encouragement to his Indian friends as scholars and writers. ${ }^{24}$ The major figures in the Indian branch of Forster scholarship include Vasant A. Shahane, Nirad Chaudhuri, G. K. Das, and C. L. Sahni, although a number of other professors, authors, and officials have written influential articles on Forster and $A$ Passage to India. ${ }^{25}$ The Indian materials naturally contain a variety of approaches

\footnotetext{
${ }^{23}$ M. Sivaramakrishna, "Marabar Caves Revisited," in Shahane, Focus on Forster's "A Passage to India," p. 16.

${ }^{24}$ Forster first visited India in 1912, and finished A Passage to India after his second visit (when he served as secretary to the Maharajah of Dewas) in 1922-23. He made a third trip to visit friends in 1945. Some of his Indian friends, including the scholars and writers he encouraged, are the authors and editors of affectionate tributes to the novelist. See especially K. Natwar-Singh, ed., E. M. Forster: A Tribute (New York: Harcourt Brace, 1964); H. H. Anniah Gowda, ed., A Garland for E. M. Forster (Mysore: Literary HalfYearly, 1969); Mulk Raj Anand, "Under the Chestnut Tree in Tavistock Square with E. M. Forster and Leonard Woolf," in Conversations in Bloomsbury (New Delhi: Arnold-Heinemann, 1981).

${ }^{25}$ Vasant $A$. Shahane is very widely acclaimed in Forster studies with many publications, including E. M. Forster: A Reassessment (New Delhi: Kitab Mihal, 1963); Perspectives on E. M. Forster's "A Passage to India" (New York: Barnes and Noble, 1968); "A Passage to India": A Study (London: Oxford University Press, 1977).

See also Nirad Chaudhuri's "Passage to and from India," Encounter 2, no. 6 (June 1954), 19-24; G. K. Das, E. M. Forster's India (Totowa, N.J.: Rowman and Littlefield, 1977); Chaman L. Sahni, Forster's "A Passage to India": The Religious Dimension (Atlantic Highlands, N.J.: Humanities Press, 1981).
} 
and rhetorics, but there are several debates that recur, expressing in the terms of their opposing arguments particular Indian concerns and specific methods for identifying "Indianness."

Whether they address Hindu or Muslim influences on the structure of the novel, commend or criticize the portraits of India and Indians, or argue for or against the historical realism of the novel, what is common to the Indian criticism is the articulated attention given to the writing position from which India and Indians are represented. The arguments critical to the debates mark the differences between the representation of India by the non-Indian and the Indian representation of Indian culture. For even though many Indian critics hail $A$ Passage to India as an emblem of British understanding of the Indian, and the first "successful" representation of Indian life, the very fact of writing by the Indian critic is a crucial disruption of the model in which British subjects write about Indian objects. Indianness is established not merely as the explanations of India that are in contradistinction to occidental misinterpretations, but as the establishment of writing positions that alter and revise the relationship between the binary poles of British writing subject and Indian object, that diversify and transform the scope, language, and criteria of the field of English literature.

In light of the Indian concern with establishing and distinguishing Indianness, it is not surprising that the Indian critics tend to analyze the novel in terms of Indian cultural influences, both Hindu and Muslim. Book-length studies by C. L. Sahni and V. A. Shahane consider the Hindu and Muslim religious and philosophical influences on the narrative structure, the resolution of dramatic conflict, and the portrayal of characters in the novel. The writers who wish to argue that the novel privileges Hinduism and utilizes Hindu symbology tend to concentrate on the novel's ending section, "Temple," whereas those who understand the novel in terms of Islamic influence tend to discuss the strength of the central protagonist, Aziz, a Muslim doctor. Other analyses also center on the question of Indian influences: essays by H. H. Anniah Gowda, M. Sivaramakrishna, and G. Nageswara Rao consider primarily Indian influences on the novel; K. Natwar-Singh, Mulk Raj Anand, Shahane, and Raja Rao establish the Indian influences on Forster the man and author. There is also considerable debate about the merits of the book as a political allegory or a religious novel, and, in addition, as to whether Forster himself was a political or a 
religious man. Sahni and Shahane expressly choose not to treat $A$ Passage to India as a political novel, preferring to consider it as a work whose ending symbolizes Hindu notions of reconciliation and unity. Forster's own claim that "in writing it . . my main purpose was not political, was not even sociological" is often cited by critics-British, American, and Indian alike-who wish to distinguish the novel as a literary object separate from the social and political conditions of which it is a product. It is worth noting that a majority of the Indian criticism that concentrates on Indian influence does not treat the novel as a political allegory of British imperialism; rather, the critics concerned with Indianness limit their discussions to questions of Indian culture and religion and do not mention either the political allegory in the novel or the political circumstances of its writing.

Some Indian critics, such as G. K. Das, do evaluate the novel primarily in terms of its political references and meanings. Das's study E. M. Forster's India (1977) examines the ways in which the Islamic conflicts with Britain during the period before the First World War enabled Forster to express at one time his sympathies toward Muslim Indians and their desires for Islamic unity, as well as his Liberal disenchantment with British imperialism. Das's book argues that it is this sympathy for Muslims which is expressed in the dimension of political allegory in A Passage to India. Referring to instances in Forster's essays that criticize British imperial policy, Das asserts that although Forster did not explicitly declare a pro-Indian position, the criticism of British policy implies a pro-Indian stance. Das argues that the novel renders with sympathy both the plight of Indian subjection during the period of British rule and the necessity for Indian independence; for these reasons Das considers the novel strongly political.

In distinct contrast, Nirad Chaudhuri (1954) and M. K. Naik (in Shahane 1975) assess the weaknesses of the novel as political allegory. It is the interventions of these two critics, I would suggest, that accomplish the greatest displacement of Anglo-American literary criticism. Because they neither limit their discussion of the novel to terms of literary and aesthetic evaluation nor reiterate praise for the novel as an emblem of the British-Indian relationship, Chaudhuri and Naik problematize the Anglo-American terms of the debate. Unlike the many Indian critics who laud the accuracy and justness of the novel's portrait of the Indian situation, Chaudhuri and Naik, each in differently 
emphasized arguments, consider the novel both an inadequate representation of Hindus and Muslims and an oversimplification, and therefore an obfuscation, of the political dimensions of Indo-British relations. Chaudhuri strongly criticizes the reduction of the "cultural apartheid" of Indo-British politics into the personalized relationship between two men, Aziz and Fielding: "At the root of all this lies the book's tacit but confident assumption that Indo-British relations presented a problem of personal behavior and could be tackled on a personal plane. They did not and could not." He further objects to the implication that India is primarily Muslim, because the Indian protagonist of the novel is the Muslim doctor Aziz; he points out that India is not only more diverse that this but also not predominantly Muslim but Hindu. In addition, Chaudhuri expresses disdain for the representation of Aziz as servile, simple, and hotheaded, arguing that many Muslims were fiercely anti-British and would not have accepted a subservient role. Naik is also critical of the novel as a portrait of race relations in the India of the 1920s: "First, considered as a historical document or a picture of race-relations, the novel is patently inadequate in conception and lop-sided in the presentation of its material." Like K. Natwar-Singh (in Shahane 1975), Naik points out that the novel collapses a notion of Indo-British relations as they existed in prewar India into that of India during the 1920s, and that this conflation renders invisible the noncooperation and civil disobedience movements of Mahatma Gandhi, as well as other organized efforts toward Indian independence which had begun by 1920. Naik argues further that the nostalgic Aziz "does not represent the average educated Nationalist Indian youth of the period. . . . Aziz, with his face turned back towards Babar and the medieval imperial glory of the Muslims, is totally unrepresentative of the mind of India during the 1920s." The novel, he adds, offers very inadequate portraits of both Islamic and Hindu beliefs: Godbole and the Hindu doctor Panna Lal are drawn from stereotypes, and the description of the Gokul Ashtami ceremony in the "Temple" section is a comic parody. ${ }^{26}$

Despite the interventions by Chaudhuri and Naik, however, there are evident limits to the degree to which the Indian scholars' articula-

\footnotetext{
${ }^{26}$ Chaudhuri, "Passage to and from India," p. 119; M. K. Naik, "A Passage to Less than India," in Shahane, Focus on Forster's "A Passage to India," p. 63.
} 
tions as a whole shift the discourse. I will discuss some of these in greater detail in the next section. For the moment it is enough to remark that because certain criteria remain unchallenged-the use of English as the language in which the intervention must be made, and Forster's English novel as object of study-neither the critical discussions about the political merits of the novel nor the debates about the religious dimension of Indian influences ever represents an exclusively Indian dialogue: that is, Indian critics addressing interpretations by other Indians. Rather, it must be emphasized that the Indian debates are always inscribed in a context already marked by the English literary critics. For example, the Indian critics who examine Hindu symbology address and specifically disagree with the Anglo-American-and not the Indian-critics who attempt to draw parallels between the novel and Hinduism. Glen O. Allen's "Structure, Symbol, and Theme in E. M. Forster's A Passage to India" (1955) interprets the structure and resolution of the novel in terms of a Hindu theme, identifying the three sections of the novel, "Mosques," "Caves," and "Temple," with the "trichotomous division" of the Hindu attitude toward life and the doctrine of salvation: Karma Marga (path of action), Jnana Marga (path of knowledge), and Bhakti Marga (path of devotion). Allen's interpretation is refuted by all of the Indian scholars who address the issue of Hindu influences and symbolism. C. L. Sahni dismisses Allen and other American critics for not shedding any light on the problem of Forster's knowledge of fundamental concepts of Indian thought and the sources of that knowledge. M. Sivaramakrishna targets Allen's "astonishing statement" that the mysticism underlying devotion to Shri Krishna amounts to an "utter renunciation of the intellect, the disintegration of the categories which make distinction, and therefore thought, possible" (p. 16). T. G. Vaidyanathan argues that the American critics have mistakenly placed undue emphasis on one branch of Hinduism, Advaita Vedanta, exaggerating it while ignoring the implications of the other branches. Thus, the Allen interpretation focuses a number of Indian concerns; as the center of certain Indian objections, the controversy foregrounds the history and context of the Indian criticism: an American elucidating Hindu concepts in Forster's novel is entirely different from an Indian, even a Muslim Indian, proposing the same. ${ }^{27}$ At issue is the position from

${ }^{27}$ Athough Das, E. M. Forster's India, treats primarily the Islamic influences on the novel, Das also criticizes Allen: "According to Allen, Forster portrays the three Hindu 
which a culture is characterized; the refutation of Allen by the Indians calls attention to the different social texts within which American and Indian criticisms are situated. In E. M. Forster: A Reassessment, Shahane, who also addresses Allen's thesis, states this premise ever so politely: "It is odd that no Indian has contributed anything significant towards interpreting A Passage to India. It may be conceded that such a critic, in a limited way, enjoys advantages denied to an Englishman or American. Trilling, says F. R. Leavis, could see 'England and the particular milieu to which Forster as a writer belongs, well from the outside.' An Indian critic is perhaps even better placed than an American in relation to $A$ Passage to India." 28 One essential component, then, of the Indianness named by Shahane is the marking of difference between the representation of India by the non-Indian and the representation by Indians of their own culture. Indianness is established, in these debates, as an explanation of India from a different social and historical writing position in contradistinction to occidental representation of Indians as Other.

\section{Critical Legacies of Orientalism}

I have suggested that within the discourse of orientalism there exists at all moments a variety of conflicting and converging discursive positions and formations. Any orthodoxy or hegemony within the discourse must always be founded on heterodoxy, a condition of difference; the simultaneous inscription of the orthodox and the heterodox is the necessary condition of any moment of the discourse. To illustrate this scene of heterodoxy, I have explored a series of heterogeneous sites of contestation: the critical role of Forster with regard to the previous tradition of British writing about India, the different discursive positions of the Anglo-American literary establishment and the Indian literary critics, and the rhetorical and interpretive diversity among the Indian critics' assessments of Forster and his work. By complicating the notion of discourse in this way, however, I do not

ways in the three parts of the novel in order to advocate that a wholesome way ought to be a combination of all three 'in proportion.' But in Hindu philosophy it is in fact thought that a life lived according to any one of the three ways actually partakes of elements of the other two, and may lead to perfection of the entire self" (pp. 141-42).

28Shahane, E. M. Forster: A Reassessment, p. 21. 
mean to underestimate the existence of powerful regulating formations within the discourse. What I address in this section is the role and power of orthodoxy in orientalist discourse. Participation in the discourse can require accommodation to its orthodox components, and despite changes in the modes of participation, the discourse may overdetermine and restrict the spectrum of differences. In this sense a discussion of how the structures of argument used in Indian criticism of $A$ Passage to India bear traces of logic inherited from British discussions is one means of elucidating the dynamic of orthodoxy within heterodox conditions.

I have already mentioned that in the 1950 and 1960 s Anglo-American criticism of Forster's novel very rarely mentioned the history of the British in India as a formative condition for the writing of the text. What is equally striking is that the analyses of the Indian critics for the most part also steered away from explicit discussion of the cultural and political imperialism through which the British occupied and managed India for nearly 150 years. In the examination of formal features of the novel-such as symbols, archetypes, and characterization-there was a tendency on the part of the literary critical establishment, both Anglo-American and Indian alike, to separate the literary and textual from the social or historical, and by implication nonliterary. In stating that the Anglo-American literary criticism about $A$ Passage to India was an extension of the tradition of British orientalism which constituted itself as a central and coherent power through the objectification of the Indian people as peripheral and Other, I have already implied that the English and American critics had a vested interest in the separation of literary and historical domains. ${ }^{29}$ For in omitting, or obfuscating, the relationships between the historical conditions of social and literary production and the structure, rhetoric, and language of the texts produced, it was possible to limit the referentiality of the text-that is, the degree to which it could be a political allegory about the decline of British influence in India, as well as a condemnation of British presence in India during the 1920s. Likewise, the Anglo-American separa-

${ }^{29} \mathrm{My}$ discussion treats British and North American literary criticism as connected and complementary traditions, which is not to ignore the differences among critics in England and in the United States but to appreciate the profound ties between, on the one hand, the two academic communities and, on the other hand, the history of political alliances and diplomatic sympathies uniting Britain and the United States during the twentieth century. 
tion of the literary from the historical narrowed the recognized scope of literary language and concerns, and produced a literary exclusivity that tended to delimit the novel as a discretely English object, inasmuch as this delimiting served to erect obstacles to Indian participation in this exclusive literary discussion.

One might suppose that with the beginning of Indian criticism of the novel, a wider discussion of the relationship between the literary and the historical would have taken place. Although this did occur to some extent, it is interesting to note the degree to which many of the Indian discussions perpetuated distinctions between the literary and the historical practiced by the Anglo-American critics, continuing, for example, a muting of the ties between Forster's text and the conditions of British rule which were the occasion for his writing the novel. Just as the occasion for the entry of the Indian critics into the discussion of English literature necessarily had to be the work of an English author, it seems equally clear that participation in the dialogue was restricted and disciplined in other ways-not only in terms of the objects of discussion but also in terms of the critical framework and possible methods used to interpret these objects.

As a result, as in the Anglo-American discussions, the situation of the novel as an expression and consequence of British rule in India is not always explicit in the Indian studies, and when it is addressed, the British presence in India is invoked as a preliminary to the praise of Forster and his work as exceptions to a long history of British misunderstanding of the Indians. Among thirty essays by Indian scholars, only two (those by Chaudhuri and Naik) are overtly critical of British representations of Indians in Forster's novel as a symptom of the British imperial tradition ruling, and misunderstanding, the Indians. Among the book-length Indian studies of $A$ Passage to India, the relationship between British rule and the writing of the novel is a central concern only in G. K. Das's E. M. Forster's India. Only here does the notion of history as a context for the writing of literature emerge as an explicit focus of the discussion. The general problem of the representation of Indians by British writers is not widely discussed in the larger body of Indian criticism, and other than the two essays by Chaudhuri and Naik, all the studies hail Forster as the first British novelist to represent Indian character and culture accurately and sympathetically. Many of the essays and tributes to Forster express similar praise and 
base their eulogies on examples of either Forster's understanding or the novel's successfully "realistic" representation of social and historical situations in India.

But the standard of realism as a predominant means by which the value of Forster's work is assessed by the Indian critics is not a neutral methodology or criterion. The model of realistic representation, based on a faith in the project of mimesis as well as an acceptance of an unproblematic relationship between representation and the historical fact represented, is strongly present in the tradition of European historical narrative. The long tradition of European historical realism relies on an accepted separation of the discourses and methodologies of science and art, between, on the one hand, a positivist paradigm which assumes the possibility of apprehending historical knowledge through the mimetic representation of events in narrative and, on the other, linguistic and literary modes of representation (the poetic and tropological); the "realist" historical project has been traditionally associated with the scientific paradigm. ${ }^{30}$ My aim here is not to discuss the validity of the notion of realistic representation, although the mimetic project is certainly a troubled and inexact one, particularly if we understand that in the act of representing, the very mark and act of representation necessarily attests to the absence ( or "difference") of the object or concept for which the mark stands, for the incommensurability of the signifier and signified. Rather, more significant to this discussion is, first, that an epistemological legacy separating the historical from the literary is accepted for the most part by the Indian critics. And second, in the few studies in which the boundaries between the historical and the literary are explored, the nineteenthcentury European notion of history as representable fact, rather than something narrativized and literary, is accepted and employed.

Thus, when the relationship between the novel and the history of British rule in India is addressed, it is evaluated in terms of its "realistic" representation of British-Indian relations. Das, for example, draws parallels between the Amritsar massacre in 1919 and the riots sur-

${ }^{30}$ The criticism of the distinction between science and art has been the subject of many studies. For example, a discussion of the poetic and tropological aspects of European historical writing is the focus of Hayden White's Metahistory: The Historical Imagination in Nineteenth-Century Europe (Baltimore: Johns Hopkins University Press, 1973). See also Dominick LaCapra, "Rhetoric and History," in History and Criticism (Ithaca: Cornell University Press, 1985). 
rounding the trial of Aziz; he further notes that the events at Amritsar included an incident involving an Englishwoman, Miss F. Marcella Sherwood, who had been "brutally assaulted by a group of Indians," after which fifty Indians were made to crawl across a public square while others were subjected to public floggings. The portrait of AngloIndian hysteria following Adela Quested's accusation of Aziz, Das suggests, alludes to these historical events, thus demonstrating Forster's sympathies for the Indians and his criticism of British imperialism. Throughout E. M. Forster's India, using the standard of realism to praise Forster, Das is concerned with recuperating Forster as a true advocate of Indian nationalism, even though Forster was not "proIndian"; he "looked at the issue between India and British Imperialism dispassionately, and although ideologically he disliked an empire, he was not carried away by his ideological differences to condemn the British Empire outright." In discussing the growing Muslim discontent as Britain and Turkey became enemies in the First World War, Das asserts that Forster defended Islamic unity through his writings, including the portrait of Aziz in A Passage to India: "Although [Forster] did not wish to support the Khilafat as an institution, he was strongly opposed to Britain's continued conflicts with Turkey after the First World War." At certain moments Das's book even verges on being an apology for the ambiguity of Forster's novel, a politicizing interpretation of Forster's apolitical stance. Although Das's book provides the most thorough argument for the political content of Forster's literary work, this sentiment that Forster was a "true friend" to Indians is repeated by almost all of the other Indian critics. Narayana Menon writes of the novel: "Today it has become synonymous with any bridge of sympathy and understanding that exists between two countries and civilizations. The intimacy with which Forster enters into the mind of Indians is astonishing, almost incredible." "To speak of Forster is, in a way, to speak of a saint," writes Raja Rao. ${ }^{31}$ One cannot but be struck by the intense desire, on Das's part and among many of the Indian critics, to find in Forster an Englishman who truly sympathizes with the Indian, and in his work a profound object of unity between Britons and Indians.

${ }^{31}$ Das, E. M. Forster's India, pp. 23-24, 55-56. Narayana Menon, "Recollection of E. M. Forster," p. 11, and Raja Rao, "Recollection of E. M. Forster," p. 15, both in NatwarSingh, E. M. Forster: A Tribute. 
The standard of realism is also used for quite a different purpose in some of the critical Indian essays. Natwar-Singh and Naik both argue that the representation of India in the novel is not realistic. NatwarSingh points out that "it depicts a pre-1914 India, and by the time it was published in 1924 events had overtaken it. It appears to be an almost anti-national book since it makes no mention of the political ferment that was going on in India in the early twenties." But although Natwar-Singh defends Forster on this account, Naik does not. Naik charges that the leveling of the pre- and postwar Indias into one produces a "serious lacuna"; the representation of India in the 1920 as one that contained elements dating from before 1914 levels and mutes the conflicts between Indian nationalists and the British in the years following the First World War. "There is not a single-not even a passing-reference in the novel to Mahatma Gandhi and the Civil Disobedience movement of 1920." Naik's observation about the novel is that it is neither realistic nor historical enough, that it obscures the history of British rule and, more important, the history of Indian opposition. In other words, the standard of realism continues to be one of the dominant discursive formations. Naik, however, employs the "realist" conclusion-that "considered as a historical document or a picture of race-relations, the novel is patently inadequate in conception and lop-sided in the presentation of its material" - to challenge the object and methods of the English tradition. ${ }^{32}$

The realist argument is most often supported by biographical forms of evidence. For example, Shahane in "Life's Walking Shadows" (Das and Beer 1979) identifies friends of Forster's who may have been the models for Aziz and Godbole; and many essays in E. M. Forster: A Tribute rely heavily on Forster's often-quoted declaration in "What I Believe" that "if I had to choose between betraying my country and betraying my friend, I hope I should have the guts to betray my country," as well as his tribute to his friend Syed Ross Masood, as

\footnotetext{
${ }^{32} \mathrm{~K}$. Natwar-Singh, "'Only Connect . . ': E. M. Forster and India," in Shahane, Focus on Forster's "A Passage to India," p. 3; M. Naik, "A Passage to Less than India," pp. 67, 63.

Other more common uses of realism as a standard of evaluation consist of demonstrating that Aziz is a credible Muslim or Godbole a convincing Hindu; these arguments are advanced by Shahane more than once in a number of different texts, as well as by Das, Anand, and others. There are those who disagree, however, such as Chaudhuri, who states, "Aziz would not have been allowed to cross my threshold," and "Godbole is not an exponent of Hinduism, he is a clown." Chaudhuri, "Passage to and from India," p. 117.
} 
evidence that Forster truly understood and sympathized with Indians and had therefore written a realistic novel about Indo-British relations. Of Masood, Forster wrote:

He woke me up out of my suburban and academic life, showed me new horizons and a new civilisation and helped me towards the understanding of a continent. Until I met him, India was a vague jumble of rajahs, sahibs, babus, and elephants, and I was not interested in such a jumble: who could be? He made everything real and exciting as soon as he began to talk, and seventeen years later when I wrote A Passage to India I dedicated it to him out of gratitude as well as out of love, for it would never have been written without him. ${ }^{33}$

There seems to be no doubt, for any of the critics writing in $E$. M. Forster: A Tribute, that the intention of the author had found its way, unmediated and unproblematized, into the form, character, and language of the novel.

The variety of arguments illustrates the diverse uses of realism as an emblem of authority; the standard by which textual representations should correspond to historical referents is employed in both the valorization and the criticism of the novel. To the extent that the invocation of the realist model is the means used by the Indians to assess and discuss the value of Forster's novel, these are examples of how "difference" gets structured by orthodox or similar models, how participation in the discourse is prefigured by the conditions of discourse. It is also an illustration of how heterodoxy-the articulation of distinctly differing ideological positions-is limited by the orthodoxy of discussions managed by the criteria of realism.

I have suggested that the entry of Indian writers into the field of Anglo-American Forster criticism emerges as one site within a series of heterogeneous and conflicted discursive moments. Not only is the British representation of the ruling British and the ruled Indians contested by novels such as those written by Candler, Thompson, and Forster, but also, as my discussion of Endrikar and Maconochie implies, even the narratives defining the centrality of British power in India prefigure a critique of that centrality. It is in the context of an already divided and heterogeneous discourse that the Indian critics' commentaries on Forster's novel intervene in the Anglo-American

${ }^{33}$ E. M. Forster, Two Cheers for Democracy (London: Edward Arnold, 1951), p. 292. 
critical tradition. Finally, the Indian criticism is itself divided in its assessment of $A$ Passage to India: the praise of Forster and his work by Shahane and Das is refuted by Chaudhuri and Naik, who analyze the inadequacies of the narrative representation of the history of race relations in India. A review of this series suggests that within each conflicted discursive site, each challenging articulation shifts the existing orthodoxy, transforming the criteria that regulate which discursive objects and methods are acceptable. In addition, not only does every orthodoxy articulate itself within the context of heterodox challenges, but every specific hegemonic formation is itself contradictory: for example, the repeated topos of the Indian's scrutinizing gaze suggests the fundamental instability of British hegemony even during the period of British rule.

I close by arguing for a greater consideration of the multivalence of the oppositional classification of cultural difference, in this case Indianness, for Indianness has a different function in each of the discursive sites considered here: the signifier Indianness is used by British narratives in the colonial period as a means of excluding and subordinating colonial subjects, whereas in the early postcolonial period Indian scholars utilized the idea to pose a countertradition within the field of English literary criticism. The Indian scholars' entrance into the discussions of Forster's novel under the signifier of "the Indianness of the native point of view" illustrates how difference can be appropriated from dominant formations and rearticulated from a different position on the discursive terrain. If one continued to map the further trajectory of sites where discussions of Indianness as difference constitute a topos, one could interpret certain postcolonial Indian intellectuals writing in the 1980s and 1990s-Homi Bhabha, Gayatri Spivak, Lata Mani, and Radha Radhakrishnan, for example-as constituting yet another, third moment of this dialogue about cultural difference. ${ }^{34}$ The articulations of these critics, heterogeneous them-

\footnotetext{
${ }^{34}$ I mention these theorists together because they share a postcolonial theoretical perspective that tends to be critical of essentializing categories such as "the Third World," or "Indianness." But it must be emphasized that among this group, too, is represented quite a heterogeneous variety of critical methods, objects, and political projects. Although both theorists make use of post-structuralist and psychoanalytic methods, the essays concerning the intersection of feminism and anticolonialism in Gayatri Spivak's In Other Worlds (London: Routledge, 1988) have a distinctly different focus from Homi K. Bhabha's discussion of the ambivalence of nationalism in Nation and
} 
selves, deconstruct and displace the uniformity of a notion of Indianness, posing critiques that specifically target the dangers of narrating Indian subalternity as an essence. Although this third moment-poststructuralist and postcolonial, as we might name it-falls outside the scope of this chapter, I gesture toward it not merely to suggest that there are other discursive loci that provide further challenges to the dominant formation of British colonialism beyond the sites discussed here, but also to signal that what I have framed is only one moment in a dynamic and ongoing series of dialogues between heterogeneous discursive sites. ${ }^{35}$

Narration (London: Routledge, 1990). Radha Radhakrishnan's discussion of Foucault and Gramsci and the role of the intellectual in local and global political practice and analysis in "Toward an Effective Intellectual," although compatible with the observations made by Lata Mani in "Multiple Mediations: Feminist Scholarship in the Age of Multinational Reception" Inscriptions 5 (1989): 1-23, does not share Mani's attention to feminist subjects and feminist politics, vividly illustrated by her focus on the construction of sati.

35In limiting my discussion to the discursive site of Forster criticism, I do not intend to generalize its patterns as being exemplary of all British and Indian dialogues, nor, most important, do I mean to limit the possible sites of resistance and intervention to the ones discussed here. For example, a juxtaposition of British colonial accounts with Indian peasant and worker narratives (such as those reconstructed by the Subaltern Studies Group) or, conversely, a focus on exclusively Indian dialogues about Indian controversies would provide very different discursive (and perhaps more radical) examples from the one examined here. Rather, I have chosen Forster criticism because it seems to me to provide one illustrative "anatomy" of intervention and accommodation in orientalist discourse; it offers one site in which to trace some of the transformations, as well as the legacies, of early orientalist arguments and rhetorics. 